\title{
Pengaruh Pengendalian Internal, Ketaatan Aturan Akuntansi Terhadap Akuntabilitas Keuangan dengan Pencegahan Kecurangan (Fraud) sebagai Variabel Intervening pada Travel Haji dan Umrah di Kotamadya Jambi
}

\author{
Mufidah, Amilia Paramita Sari \\ Fakultas Ekonomi, Universitas Batanghari
}

\begin{abstract}
The purpose of this study is to analyze the influence of internal control, Obedience of accounting rules to financial accountability through fraud prevention as intervening variable at Hajj Umroh Travel in Jambi Municipality. The type of this research is descriptive which is a survey on Hajj and Umroh Travel in Jambi Municipality. Data collection with literature study and field study. The time period used is cross sectional conducted in April - May 2018. The number of respondents is 37 hajj and umroh travel in Jambi Municipality. Data analysis for hypothesis testing using inferential statistic was measured using Partial Least Square (PLS).
\end{abstract}

Keywords: Internal Control, Fraud, Accountability

\section{PENDAHULUAN}

Antrean haji yang sangat panjang membuat masyarakat Muslim Indonesia memilih untuk menunaikan ibadah umrah terlebih dahulu.Permintaan (demand) akan jasa pelayanan travel haji dan umrah selalu melampaui suplai dan terus meningkat dari tahun ke tahun.Tapi, berbagai masalah kerap kali muncul terkait penyelenggaraan umrah yang berujung pada dirugikannya jamaah.Pemerintah pun didesak ikut mengatasi berbagai persoalan tersebut, termasuk membenahi regulasi penyelenggaraan umrah. Mengutip Data Ditjen Penyelenggaraan Haji dan Umrah Kementerian Agama, sejak Desember 2015 hingga Maret 2016, tercatat ada 10.772 calon jemaah yang gagal ke Tanah Suci akibat biro travel umrah bertarif murah. Para biro maupun agen cuma mencari keuntungan semata, menghimpun dana dari para calon murah, tetapi uangnya dipakai untuk berinvestasi di tempat lain.Kisruh pelayanan umrah bodong yang dituduhkan kepada PT First Anugerah Karya Wisata (First Travel) membuka tabir persaingan bisnis perjalanan umrah. Perusahaan tersebut membuat jemaah umrah batal pergi ke Tanah Suci. Pemerintah melalui Kementerian Agama, segera membereskan permasalahan yang terjadi pada perjalanan haji dan umrah, salah satunya praktik marak biro umrah bertarif murah.

Mencuatnya kasus First Travel menjelang musim haji 2017 cukup mencoreng dunia usaha travel haji dan umrah di Indonesia. Banyak yang mengaitkan kasus ini dengan gaya hidup mewah pemilik First Travel.Gaya hidup mewah tim manajemen First Travel menjadi sorotan publik dengan didasari dugaan bahwa ke sanalah dana jamaah dilarikan. Ada juga yang berhipotesa bahwa First Travel menerapkan skema Ponzi karena biaya layanan yang ditawarkan murah. Investasi yang salah untuk memutar dana ditengarai juga menjadi salah satu penyebab masalah. Menurut Tuannakota (2013), Fraud adalah kejahatan yang dapat ditangani dengan dua cara, yaitu mencegah dan mendeteksi.

Pengaruh Pengendalian Internal, Ketaatan Aturan Akuntansi Terhadap Akuntabilitas Keuangan dengan Pencegahan Kecurangan (Fraud) sebagai Variabel Intervening pada Travel Haji dan Umrah di Kotamadya Jambi 
Para ahli memperkirakan bahwa fraud yang terungkap merupakan bagian kecil dari seluruh fraud yang sebenarnya terjadi. Oleh karena itu upaya utama seharusnya pada pencegahan. Cara- cara mencegah fraud dimulai dengan lingkungan pengendalian intern yang secara khusus mencegah fraud ( fraud specific internal control).

Harta kekayaan dari berbagai kejahatan tersebut umumnya tidak langsung digunakan oleh pelaku kejahatan karena akan mudah dilacak oleh penegak hukum. Mereka biasanya lebih dahulu berupaya memasukkan kekayaan tersebut ke dalam system keuangan (financial system). Mereka mengharapkan asal - usul kekayaan tidak dapat dilacak. Upaya untuk menyembunyikan atau menyamarkan asal-usul kekayaan yang diperoleh dari tindak pidana ini dikenal sebagai pencucian uang. Pada bulan juni 2001, Indonesia dimasukkan ke dalam daftar NCCTs bersama-sama 19 negara lainnya. kelemahan yang disoroti oleh FATF adalah tidak adanya undang-undang yang menetapkan pencucian uang sebagai tindak pidana, tidak adanya ketentuan Prinsip mengenal nasabah atau Know Your Customer Principles (KYC) untuk lembaga keuangan non-bank, rendahnya kualitas SDM dalam penanganan kejahatan pencucian keuangan non-bank, rendahnya kualitas SDM dalam penanganan kejahatan pencucian uang, dankurangnya kerjasama internasional. Hal ini mendorong pemerintah mengambil langkah-langkah untuk mengatasi kelemahan yang disoroti oleh FATF, kemudian pemerintah mengesahkan Undang-undang Nomor 15 tahun 2002 tentang Tindak Pidana Pencucian Uang. Pusat Pelaporan dan Analisis Transaksi Keuangan (PPATK) dibentuk sebagai lembaga independen dalam melaksanakan tugas dan kewenangannya untuk mencegah dan memberantas tindak pidana pencucian uang. (Tuannakota,2013)

Kemenag melakukan langkah untuk memverifikasi dan penelitian kembali terhadap persyaratan menjadi Penyelenggara Pemberangkatan Ibadah Umrah (PPIU). Pada tahap ini sebuah PPIU harus mendapat akreditasi lima poin, yaituAdministrasi dan manajemen, finansial, sarana dan prasarana oleh PPIU itu, SDM jumlah pengelolanya, dan kualitas pelayanan. Jadi selama 3 tahun terakhir, dicek bagaimana pelayanannya memenuhi standar minimal atau tidak. Untuk finansial harus mempunyai bank garansi dan laporan keuangan yang telah diaudit oleh kantor akuntan Publik. Oleh karena itu perusahaan-perusahaan travel haji dan Umrah harus memiliki pengendalian internal yang efektif dan ketaatan aturan akuntansi sehingga dapat mencegah dari timbulnya kecurangan sehingga tercipta akuntabilitas keuangan. Dengan adanya akuntabilitas keuangan ini memberikan pengaruh yang besar terhadap rekomendasi pertimbangan yang baik dari kemenag sehingga dapat diperpanjang izin PPIU dan akuntan publik dapat memberikan opini wajar tanpa pengecualian serta masyarakat dan jamaah dapat menjadikan bertambahnya kepercayaan masyarakat dalam beribadah Umrah di travel haji dan Umrah di Kotamadya Jambi ini. Berdasarkan latar belakang masalah dan penelitian terdahulu , maka rumusan masalah dari penelitian ini adalah sebagai berikut: (1) Bagaimanakah pengaruh pengendalian internal terhadap pencegahan kecurangan pada Travel Haji Umrah di Kotamadya Jambi ? (2) Bagaimanakah pengaruh ketaatan aturan akuntansi terhadap pencegahan kecurangan ( fraud ) pada Travel Haji Umrah di Kotamadya

Pengaruh Pengendalian Internal, Ketaatan Aturan Akuntansi Terhadap Akuntabilitas Keuangan dengan Pencegahan Kecurangan (Fraud) sebagai Variabel Intervening pada Travel Haji dan Umrah di Kotamadya Jambi 
Jambi? (3) Bagaimanakan pengaruh pengendalian internal terhadap akuntabilitas keuangan pada Travel Haji Umrah di Kotamadya Jambi? (4) Bagaimanakah pengaruh ketaatan aturan akuntansi terhadap akuntabilitas keuangan pada Travel Haji Umrah di Kotamadya Jambi? (5) Bagaimanakah pengaruh pengendalian internal dan ketaatan aturan akuntansi terhadap akuntabilitas keuangan melalui pencegahan kecurangan ( fraud) pada Travel Haji Umrah di Kotamadya Jambi?

Berdasarkan latar belakang dan perumusan masalah yang diuraikan diatas maka tujuan penelitian adalah sebagai berikut: (1) Untuk menganalisis pengaruh pengendalian internal terhadap pencegahan kecurangan (fraud) pada Travel Haji Umrah di Kotamadya Jambi. (2) Untuk menganalisis pengaruh ketaatan aturan akuntansi terhadap pencegahan kecurangan (fraud) pada Travel Haji Umrah di Kotamadya Jambi. (3) Untuk menganalisis pengaruh pengendalian internal terhadap akuntabilitas keuangan pada Travel Haji Umrah di Kotamadya Jambi. (4) Untuk menganalisis pengaruh ketaatan aturan akuntansi terhadap akuntabilitas keuangan pada Travel Haji Umrah di Kotamadya Jambi. (5) Untuk menganalisis pengaruh pengendalian internal dan ketaatan aturan akuntansi terhadap akuntabilitas keuangan melalui pencegahan kecurangan (fraud) pada Travel Haji Umrah di Kotamadya Jambi.

\section{Landasan Teori dan Hipotesis Pengendalian Internal}

Menurut Krismiaji (2010) mengemukakan pengendalian intern adalah, Pengendalian intern adalah rencana organisasi dan metode yang digunakan untuk menjaga atau melindungi aktiva, menghasilkan informasi yang akurat dan dapat dipercaya,memperbaiki efisiensi, dan untuk mendorong ditaatinya kebijakan manajemen. Sedangkan menurut SA Seksi 319 Pertimbangan atas Pengendalian Intern dalam Audit Laporan Keuangan paragraf 06 dalamMulyadi (2002) mendefinisikan"pengendalian adalah suatu proses yang dipengaruhi oleh dewan komisaris, manajemen, dan personil satuan usaha lainnya, yang dirancang untuk mendapat keyakinan memadai tentang pencapaian tujuan dalam hal-halberikut: Keandalan pelaporan keuangan, Kesesuaian dengan undang-undang peraturan yang berlaku, dan efektifitas dan efesiensi operasi”.Berdasarkan SA Seksi 319 Pertimbangan atas Pengendalian Intern dalam Audit Laporan Keuangan paragraf 07 dalam Mulyadi (2002) menyebutkan lima unsur pokok pengendalian intern yaitu:

a. Lingkungan Pengendalian

Lingkungan pengendalian menetapkan corak suatu organisasi, mempengaruhi kesadaran pengendalian orang-orangnya. Lingkungan pengendalian merupakan dasar untuk semua komponen pengendalian intern, menyediakan disiplin dan intern.

b. Perhitungan Risiko

Penaksiran risiko adalah identifikasi entitas dan analisis terhadap risiko yang relevan untuk mencapai tujuannya, membentuk suatu dasar untuk menentukan bagaimana risiko harus dikelola. Penentuan risiko tujuan laporan keuangan adalah identifikasi organisasi, analisis, dan manajemen risiko yang berkaitan dengan pembuatan laporan keuangan yang disajikan sesuai dengan prinsip akuntansi .

Pengaruh Pengendalian Internal, Ketaatan Aturan Akuntansi Terhadap Akuntabilitas Keuangan dengan Pencegahan Kecurangan (Fraud) sebagai Variabel Intervening pada Travel Haji dan Umrah di Kotamadya Jambi 
c. Aktivitas Pengendalian

Aktivitas pengendalian adalah kebijakan dan prosedur yang membantu menjamin bahwa arahan manajemen dilaksanakan. Aktivitas tersebut membantu memastikan bahwa tindakan yang diperlukan untuk menanggulangi risiko dalam pencapaian tujuan entitas.

d. Informasi dan Komunikasi

Komunikasi menyangkut penyampaian informasi kepada semua yang terlibat dalam pelaporan keuangan agar mereka memahami bagaimana aktivitasnya berhubungan dengan pekerjaan orang lain, baik di dalam organisasi maupun luar organisasi.

e. Pemantauan

Pemantauan adalah proses yang menetukan kualitas kinerja pengendalian intern sepanjang waktu. Pemantauan mencakup penentuan desain dan operasi pengendalian tepat waktu dan pengambilan tindakan koreksi.Tujuan pemantauan adalah untuk menentukan apakah pengendalian masih berjalan sesuai dengan tujuan yang ingin dicapai atau perlu adanya perbaikan.

Pengendalian internal memiliki keterbatasan . Keterbatasan pengendalian internal tersebut menurut mulyadi (2002) adalah :

a. Kesalahan dalam pertimbangan

Kesalahan dalam mempertimbangkan keputusan bisnis yang diambil atau dalam melaksanakan tugas rutin yang biasanya dilakukan oleh manajemen atau personel lain. Kesalahan ini dapat disebabkan oleh tidak memadainya informasi yang diterima, keterbatasan waktu dan tekanan lainnya.

b. Gangguan

Adanya kekeliruan dalam memahami perintah, terjadinya kesalahan karena kelalaian dan perubahan yang bersifat sementara atau permanent dalam personil atau dalam system dan prosedur yang diterapkan.

c. Kolusi

Kerjasama antara pihak - pihak yang terkait, yang mana seharusnya antara pihak - pihak tersebut saling mengawasi, tetapi malah saling bekerja sama untuk menutupi kesalahan - kesalahan yang dibuat baik secara sengaja maupun tidak sengaja.

d. Pengabaian oleh manajemen

Manajemen mengabaikan kebijakan dan prosedur yang telah diterapkan semata - mata untuk kepentingan pribadinya sehingga pengendalian internal tidak berfungsi secara baik.

e. Biaya lawan manfaat

Biaya yang telah dikeluarkan untuk penerapan pengendalian internal tidak boleh melebihi manfaat yang diharapkan dari adanya penerapan pengendalian internal tersebut.

\section{Ketaatan Aturan Akuntansi}

Kamus Besar Bahasa Indonesia (KBBI) mengartikan taat yaitu senantiasa tunduk/tidak berlaku curang. Menurut Rahmawati (2012) aturan merupakan tindakan atau perbuatan yang harus dijalankan. Aturan akuntansi dibuat sedemikian rupa sebagai dasar dalam penyusunan laporan keuangan. Dalam

Pengaruh Pengendalian Internal, Ketaatan Aturan Akuntansi Terhadap Akuntabilitas Keuangan dengan Pencegahan Kecurangan (Fraud) sebagai Variabel Intervening pada Travel Haji dan Umrah di Kotamadya Jambi 
standar akuntansi terdapat aturan-aturan yang harus digunakan dalam pengukuran dan penyajian laporan keuangan yang berpedoman terhadap aturan - aturan yang dikeluarkan oleh IAI .

\section{Akuntabilitas Keuangan}

Mahmudi (2005), Akuntabilitas (accountability) adalah kewajiban untuk memberikan pertanggungjawaban atau menjawab dan menerangkan kinerja serta tindakan seseorang badan hukum pimpinan suatu organisasi kepada pihak yang memiliki hak atau berkewenangan untuk meminta keterangann atau pertanggungjawaban. Suatu entitas (atau organisasi) yang accountable adalah entitas yang mampu menyajikan informasi secara terbuka mengenai keputusankeputusan yang telah diambil selama beroperasinya entitas tersebut, memungkinkan pihak luar (misalnya legislatif, auditor, atau masyarakat luas) mereview informasi tersebut, serta bila dibutuhkan harus ada kesediaan untuk mengambil tindakan korektif.

Prinsip akuntabilitas adalah merupakan pelaksanaan pertanggungjawaban dimana dalam kegiatan yang dilakukan oleh pihak yang tekait harus mampu memper tanggungjawabkan pelaksanaan kewenangan yang diberikan di bidang tugasnya. Prinsip akuntabilitas terutama berkaitan erat dengan pertanggungjawaban terhadap efektivitas kegiatan dalam pencapaian sasaran atau target kebijakan atau program yang telah ditetapkan itu .

Peningkatkan efisiensi, laporan pertanggungjawaban harus memiliki karakteristik sebagai berikut (Siregar, 2017) :

1. Laporan harus sesuai dengan struktur organisasi . Laporan harus ditujukan terutama kepada individu yang bertanggung jawab untuk mengendalikan aktivitas yang dicangkup dalam laporan .

2. Laporan harus konsisten bentuk dan isinya setiap diterbitkan .

3. Laporan harus tepat waktu

4. Laporan harus diterbitkan secara teratur

5. Laporan harus mudah dipahami

6. Laporan memuat perincian yang memadai , tetapi tidak berlebihan

7. Laporan harus menyajikan data perbandingan ( membandingkan anggaran atau standar yang sudah ditentukan dengan hasil sesungguhnya ). Penyimpangan yang signifikan harus ditonjolkan sehingga manajer pusat pertanggungjawaban dapat mengidentifikasi masalah tersebut dengan cepat.

8. Laporan harus analitis

9. Laporan untuk manajer operasi harus menyajikan informasi mengenai unit fisik sekaligus jumlah rupiahnya.

\section{Pencegahan kecurangan ( Fraud)}

Davia et al (2000) mengelompokan fraud dalam tiga kelompok sebagai berikut :

1. Fraud yang sudah ada tuntutan hukum (prosecution), tanpa memperhatikan bagaimana keputusan pengadilan

2. Fraud yang ditemukan, tetapi belum ada tuntutan hokum

3. Fraud yang belum ditemukan

Pengaruh Pengendalian Internal, Ketaatan Aturan Akuntansi Terhadap Akuntabilitas Keuangan dengan Pencegahan Kecurangan (Fraud) sebagai Variabel Intervening pada Travel Haji dan Umrah di Kotamadya Jambi 
Para ahli memperkirakan bahwa fraud yang terungkap merupakan bagian kecil dari seluruh fraud yang sebenarnya terjadi. Oleh karena itu, upaya utama seharusnya adalah pada pencegahannya Ungkapan yang menjelaskan akar pemasalahan atau penyebab dari fraud, yaitu Fraud by need, by greed, and by opportunity. Unsur by opportunity dalam ungkapan tersebut biasanya ditekan melalui pengendalian intern. Secara skematis, Association of Certified Fraud Examiners (ACFE) menggambarkan occupational fraud dalam bentuk fraud tree . Occupational fraud tree ini mempunyai tiga cabang utama, yakni corruption, asset missappropriaton dan fraudulent statements. Aset misappropriation atau "pengambilan" aset secara illegal (tidak sah, atau melawan hukum) yang dilakukan oleh seseorang yang diberi wewenang untuk mengelola atau mengawasi aset tersebut, disebut mengelapkan. Istilah pencurian dalam fraud tree disebut larceny. Istilah penggelapan dalam bahasa Inggrisnya adalah embezzlement .Contoh : pencurian barang di gudang oleh kepala gudang disebut embezzlement . Lacerny atau pencurian adalah bentuk penjarahan yang paling kuno dan dikenal sejak awal peradaban manusia .Peluang untuk terjadinya penjarahan jenis ini berkaitan erat dengan lemahnya sistem pengendalian intern, khususnya yang berkenaan dengan perlindungan keselamatan aset. (Tuannakota, 2013).

Dorminey, dkk (2012) mengungkapkan bahwa pengendalian internal berurusan terutama dengan aspek peluang kejahatan. Pelaksanaan yang tepat dari lingkungan pengendalian dapat mempengaruhi dari kemungkinan tindakan tersebut, dengan evaluasi potensi penipuan yang tersembunyi. Bahkan jika pelaku mampu melaksanakan tindakan, kemungkinan penemuan ditingkatkan melalui lingkungan pengendalian internal, sehingga dapat berpengaruh negatif terhadap penipuan yang tersembunyi.

\section{Hipotesis}

1. Pengendalian internal berpengaruh terhadap pencegahan kecurangan (fraud) pada Travel Haji Umrah di Kotamadya Jambi.

2. Ketaatan aturan akuntansi berpengaruh terhadap pencegahan kecurangan ( fraud ) pada Travel Haji Umrah di Kotamadya Jambi.

3. Pengendalian internal berpengaruh terhadap akuntabilitas keuangan pada Travel Haji Umrah di Kotamadya Jambi.

4. Ketaatan aturan akuntansi berpengaruh terhadap akuntabilitas keuangan pada Travel Haji Umrah di Kotamadya Jambi.

5. Pengendalian internal dan ketaatan aturan akuntansi berpengaruh terhadap akuntabilitas keuangan melalui pencegahan kecurangan (fraud) pada Travel Haji Umrah di Kotamadya Jambi.

\section{METODE}

Jenis data yang akan digunakan dalam penelitian adalah data primer dan data sekunder. Data primer berupa hasil jawaban responden atas pertanyaan dalam kuisioner mengenai pengendalian internal. Sedangkan data sekunder berupa bukti, catatan dan laporan historis mengenai perusahaan. Populasi dalam penelitian ini adalah Pimpinan, karyawan atau pegawai dari bagian-bagiandi travel haji dan Umrah di kotamadya Jambi yaitu sebanyak 34 perusahaan . Pemilihan sampel berdasarkan metode purposive sampling dengan tujuan mendapatkan sampel yang

Pengaruh Pengendalian Internal, Ketaatan Aturan Akuntansi Terhadap Akuntabilitas Keuangan dengan Pencegahan Kecurangan (Fraud) sebagai Variabel Intervening pada Travel Haji dan Umrah di Kotamadya Jambi 
representatif sesuai dengan kriteria yang ditentukan. Kriteria perusahaan yang dijadikan sampel dalam penelitian ini adalah perusahaan yang terdaftar resmi izinnya pada penyelenggara perjalanan ibadah umrah di Provinsi Jambi (B630/Kw.05.4/HJ.00/02/2018), yaitu sebanyak 10 (sepuluh) perusahaan di Provinsi Jambi. Pemilihan berdasarkan izin resminya dikarenakan banyaknya travel yang terdaftar namun tidak mempunyai kantor dan pegawai hanya perangkapan usaha lain yang memakai nama travel dari daerah - daerah di pulau Jawa. Sehingga hanya 8 (delapan) perusahaan yang berdomisili di Kotamadya Jambi yang benar - benar mempunyai kantor dan administratif yang lengkap yang terdaftar di Kemenag Provinsi sehingga sampel yang diambil hanya delapan perusahaan dengan masing - masing perusahaan dibagikan 3 Quisioner untuk manajer , accounting dan adminnya.

\section{Tabel 1}

Kriteria Pengambilan Sampel

\begin{tabular}{|c|c|}
\hline Kriteria & Perusahaan \\
\hline $\begin{array}{l}\text { Perusahaan yang mendaftar pada Kantor Kesehatan } \\
\text { Pelabuhan Jambi }\end{array}$ & 34 \\
\hline Perusahaan yang memiliki izin resmi di Provinsi Jambi & 10 \\
\hline $\begin{array}{l}\text { Perusahaan yang berdomisili di Kotamadya Jambi dan yang } \\
\text { mengembalikan kuesioner }\end{array}$ & 8 \\
\hline
\end{tabular}

Sumber: Data diolah

\section{Metode Analisis Data}

Metode analisis data dalam penelitian ini menggunakan analisis statistic deskriptif dan analisis statistic inferensial yaitu:

1. Analisis Statisitik Deskriptif

2. Analisis statistic Inferensial

Sesuai dengan hipotesis yang telah dirumuskan, maka dalam penelitian ini analisis statisitik inferensial diukur dengan menggunakan Partial Least Square (PLS) yaitu software Smart PLS mulai dari pengukuran model ( outer model) , struktur model (inner model) dan pengujian hipotesis (ghozali dan latan:2015). Metode PLS mempunyai keunggulan sendiri diantaranya : data tidak harus berdistribusi normal multivariate dan ukuran sampel tidak harus besar. (Ghozali : 2006 )

Langkah-langkah dalam analisis PLS sebagai berikut :

a) Perancangan Model Struktural (inner model)

Inner model atau Model structural mengambarkan hubungan antar variabel laten berdasarkan pada substantive theory . Perancangan Model Struktural hubungan antar variabel laten didasarkan pada rumusan masalah atau hipotesis penelitian.

b) Merancang Model Pengukuran (outer model)

c) Menkontruksi diagram jalur

Langkah setelah melakukan perancangan inner model dan outer model dinyatakan dalam bentuk diagram jalur. Bentuk diagram jalur perancangan inner model dan outer model dalam penelitian diilustrasikan pada Gambar 1.

d) Konversi diagram jalur ke dalam sistem persamaan

Pengaruh Pengendalian Internal, Ketaatan Aturan Akuntansi Terhadap Akuntabilitas Keuangan dengan Pencegahan Kecurangan (Fraud) sebagai Variabel Intervening pada Travel Haji dan Umrah di Kotamadya Jambi 
- Evaluasi Outer Model

Pada model PLS terdapat outer model sebagai berikut :

1. Variabel pengendalian internal $\left(\mathrm{X}_{1}=\lambda_{\mathrm{x} 1} \xi_{1+\delta 1}\right)$

2. Variabel Ketaatan Aturan Akuntansi $\left(X_{2}=\lambda_{x 2} \xi_{2}+\delta_{2}\right)$

3. Variabel Pencegahan Kecurangan $\left(\mathrm{X}_{3}=\lambda_{\times 3} \eta_{\left.1+\varepsilon_{1}\right)}\right.$

4. Variabel Akuntabilitas Keuangan $\left(\mathrm{y}_{1}=\lambda \mathrm{y}_{1} \eta_{2}+\varepsilon_{1}\right)$

- Evaluasi Inner Model

Pada model PLS inner model dinyatakan dalam sistem persamaan sebagai berikut :

e) Estimasi

$\eta_{1}=\gamma_{1} \xi_{1+} \gamma_{2} \xi_{2+} \zeta_{1, \text { dan }} \eta_{2}=\beta_{1} \eta_{1}+\gamma_{3} \xi_{1}+\zeta_{2}$

Statistik uji yang digunakan adalah statistic $\mathrm{t}$ atau uji $\mathrm{t}$. Pengujian dilakukan dengan t-test, bilamana diperoleh $p$-value $\leq 0,05$ (alpha $5 \%$ ), maka disimpulkan signifikan, dan sebaliknya .

f) Goodness of fit

Goodness of fit dalam PLS dibagi menjadi dua bagian yaitu:

a. Outer model

b. Inner model

g) Pengujian Hipotesis

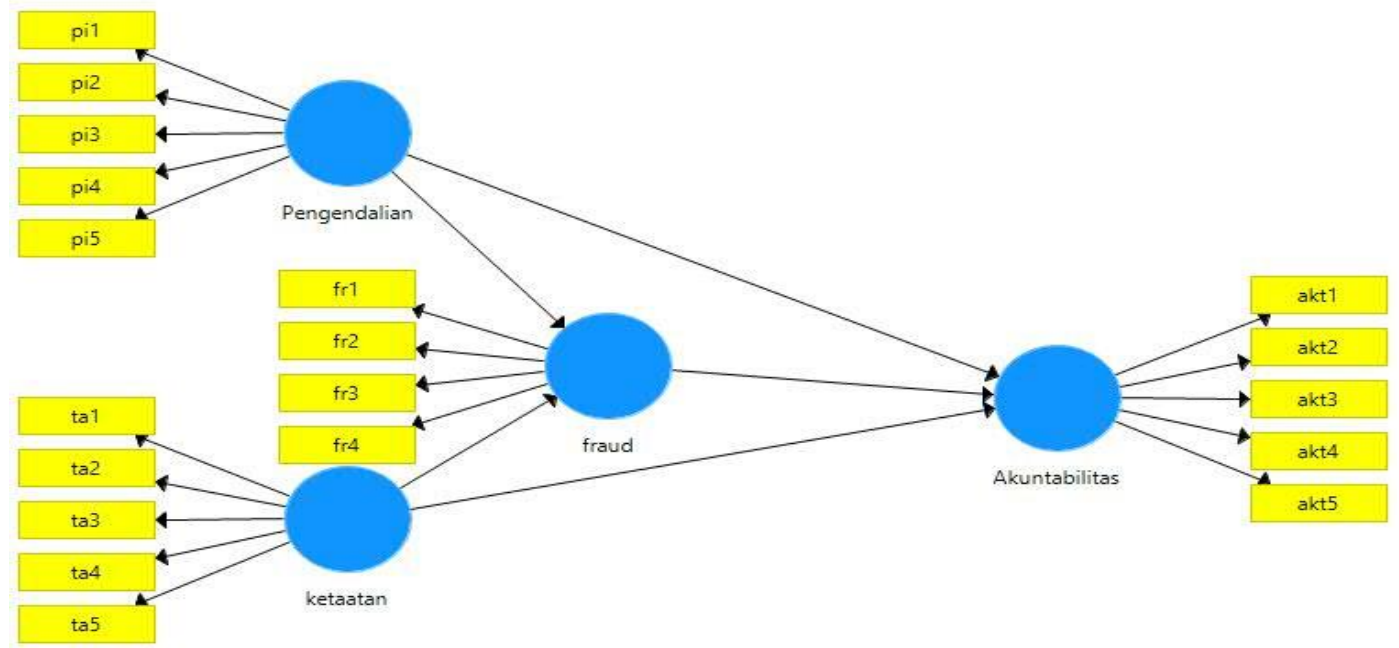

Gambar 1.

Diagram Jalur Penelitian

\section{Operasional Variabel Penelitian}

Operasional variabel diperlukan untuk menentukan jenis, indikator, ukuran serta skala dari variabel-variabel yang terkait dalam penelitian, sehingga pengujian hipotesis dengan alat bantu statistik dapat dilakukan dengan benar. Berikut ini pembahasan defenisi operasional yang menjelaskan variabel-variabel yang digunakan dalam penelitian ini.

1. Pengendalian internal $\left(X_{1}\right)$, adalah suatu rencana organisasi dan semua ukuran-ukuran dan prosedur-prosedur yang dibuat dalam suatu perusahaan untuk tujuan:

1) mengamankan harta,

2) mendorong ketaatan terhadap kebijaksanaan perusahaan,

Pengaruh Pengendalian Internal, Ketaatan Aturan Akuntansi Terhadap Akuntabilitas Keuangan dengan Pencegahan Kecurangan (Fraud) sebagai Variabel Intervening pada Travel Haji dan Umrah di Kotamadya Jambi 
3) meningkatkan efisiensi usaha dan

4) menjamin adanya catatan akuntansi yang akurat dan dapat dipercaya (Dunia, 2013).

Dimensi yang digunakan untuk mengukur konsep ini adalah:

1) Lingkungan Pengendalian,

2) Penilaian Resiko,

3) Aktivitas Pengendalian,

4) Pemantauan dan

5) Informasi dan komunikasi.

2. Ketaatan Aturan Akuntansi $\left(\mathrm{X}_{2}\right)$ merupakan aturan-aturan yang harus digunakan dalam pengukuran dan penyajian laporan keuangan yang berpedoman terhadap aturan-aturan yang dikeluarkan oleh IAI.

3. Pencegahan kecurangan/Fraud $\left(\mathrm{Y}_{1}\right)$ dimensi yang digunakan untuk mengukur konsep ini adalah: (1) Inventarisasi, (2) Pemisahan fungsi, (3) Dokumen dan (4) Pengamanan.

4. Akuntabilitas $\left(\mathrm{Y}_{2}\right)$ adalah entitas yang mampu menyajikan informasi secara terbuka mengenai keputusan-keputusan yang telah diambil selama beroperasinya entitas tersebut, memungkinkan pihak luar mereview informasi tersebut serta bila dibutuhkan harus ada kesediaan untuk mengambil tindakan korektif.

Menurut Agustiawan (2016) dimensi-dimensi akuntabilitas yang digunakan adalah akuntabilitas keuangan, akuntabilitas hierarkikal, akuntabilitas professional dan akuntabilitas legal.

\section{HASIL DAN PEMBAHASAN}

Penelitian ini menggunakan 4 (empat) variabel laten yang terdiri dari 2 (dua) variabel eksogen dan dua variabel endogen. Variabel eksogen berupa variabel pengendalian internal dan ketaatan aturan akuntansi. Untuk mempermudah menganalisis data hasil penelitian digunakan pedoman kaegorisasi rata- rata skor tanggapan responden didasarkan pada Cooper \& Schindler (2006) bahwa untuk data ordinal atau data interval/rasio yang memiliki distribusi asimetris, ukuran pemusatan dapat dilakukan melalui distribusi rentang antar kuartil. Kuartil pertama sama dengan persentil ke-25, kuartil kedua (median) sama dengan persentil ke-50 dan kuartil ketiga sama dengan persentil ke-75. Pada data kuesioner yang menggunakan skala 1 - sampai 5 , dimana nilai minimum $=1$, nilai maksimum $=5$, kuartil pertama $(\mathrm{Q} 1)=2$, kuartil kedua $(\mathrm{Q} 2)=3$ dan kuartil ketiga $(\mathrm{Q} 3)=4$, maka rata-rata skor jawaban responden dapat dikategorikan berdasarkan interval seperti pada Tabel 2 berikut:

Tabel 2

Pedoman Kategorisasi Rata- Rata Skor Tanggapan Responden

\begin{tabular}{cl}
\hline Interval Skor & \multicolumn{1}{c}{ Kategori } \\
\hline $1-2$ & Buruk / Sangat rendah/ Tidak Pernah \\
$>2-3$ & Kurang/ Rendah/ Kadang- kadang \\
$>3-4$ & Cukup / Sering \\
$>4-5$ & Baik/ Tinggi / Selalu \\
\hline
\end{tabular}

Sumber: Cooper \& Schindler (2006)

Pengaruh Pengendalian Internal, Ketaatan Aturan Akuntansi Terhadap Akuntabilitas Keuangan dengan Pencegahan Kecurangan (Fraud) sebagai Variabel Intervening pada Travel Haji dan Umrah di Kotamadya Jambi 
Tanggapan dari responden yang terdapat di dalam 8 (delapan) travel umrah untuk variabel pengendalian internal, ketaatan aturan akuntansi, pencegahan kecurangan (fraud), dan akuntabilitas disajikan pada Tabel 3 dan Tabel 4 berikut ini :

Tabel 3

Rekapitulasi Rata- Rata Skor Penilaian Responden Mengenai Pengendalian Internal

\begin{tabular}{lcc}
\hline \multicolumn{1}{c}{ Dimensi } & Rata- rata Skor & Kriteria \\
\hline Lingkungan Pengendalian & 4,67 & Baik \\
Penilaian Resiko & 4,45 & Baik \\
Aktivitas Pengendalian & 3,62 & Cukup \\
Informasi Komunikasi & 4,64 & Baik \\
Pemantauan & 4,54 & Baik \\
Pengendalian Internal & $\mathbf{4 , 3 9}$ & Baik \\
\hline
\end{tabular}

Sumber : Hasil Penelitian tahun 2018 (diolah dari kuesioner)

Tabel 4

Rekapitulasi Rata- Rata Skor Penilaian Responden Mengenai Ketaatan Aturan Akuntansi

\begin{tabular}{lcc}
\hline \multicolumn{1}{c}{ Dimensi } & Rata- rata Skor & Kriteria \\
\hline Tingkat Kesesuaian Pelaksanaan Prosedur & 4,62 & Baik \\
Akuntansi & & \\
Penyajian Laporan Keuangan beserta Seluruh & 4,54 & Baik \\
Bukti Pendukungnya & & \\
Prosedur Pengelolaan Aset Organisasi & 4,45 & Baik \\
Pelaporan ke Pajak & 4,29 & Baik \\
Penyusunan Laporan Keuanganberdasarkan & 4,54 & Baik \\
SAK & & \\
Ketaatan aturan akuntansi & $\mathbf{4 , 4 9}$ & Baik \\
\hline
\end{tabular}

Sumber : Hasil Penelitian tahun 2018 ( diolah dari kuesioner )

Tabel 5

Rekapitulasi Rata- rata skor penilaian responden mengenai Pencegahan Kecurangan

\begin{tabular}{lcc}
\hline \multicolumn{1}{c}{ Dimensi } & Rata- rata Skor & Kriteria \\
\hline Inventarisasi Aset & 4,5 & Baik \\
Pemisahan fungsi & 4,41 & Baik \\
Dokumen & 4,54 & Baik \\
Pengamanan & 4,5 & Baik \\
Pencegahan Kecurangan ( Fraud) & $\mathbf{4 , 4 8}$ & Baik \\
\hline
\end{tabular}

Sumber : Hasil Penelitian tahun 2018 ( diolah dari kuesioner )

Tabel 6

Rekapitulasi Rata- rata skor penilaian responden mengenai Akuntabilitas

\begin{tabular}{ccc}
\hline Dimensi & Rata- rata Skor & Kriteria \\
\hline Akuntabilitas Kinerja & 4,41 & Baik
\end{tabular}

Pengaruh Pengendalian Internal, Ketaatan Aturan Akuntansi Terhadap Akuntabilitas Keuangan dengan Pencegahan Kecurangan (Fraud) sebagai Variabel Intervening pada Travel Haji dan Umrah di Kotamadya Jambi 


$\begin{array}{lcc}\text { Akuntabilitas Keuangan } & 4,45 & \text { Baik } \\ \text { Akuntabilitas Hierarkikal } & 4,70 & \text { Baik } \\ \text { Akuntabilitas Profesional } & 4,37 & \text { Baik } \\ \text { Akuntabilitas Legal } & 4,54 & \text { Baik } \\ \text { Akuntabilitas } & \mathbf{4 , 5} & \text { Baik }\end{array}$

Sumber : Hasil Penelitian tahun 2018 ( diolah dari kuesioner)

Pada tabel 2 sampai dengan 6 secara keseluruhan variabel pengendalian internal, ketaatan aturan akuntansi memiliki rata-rata skor sebesar 4,44 (88,8\%) yang termasuk kategori tinggi. Hal ini dapat menunjukan bahwa pengendalian internal dan ketaatan aturan akuntansi telah berjalan dengan baik, namun dari sisi dimensi aktivitas pengendalian pada variabel pengendalian internal baru memasuki kategori cukup atau masih kurang optimal.

\section{Analisis Statistik Inferensial}

Analisis statistik inferensial pengolahannya dilakukan menggunakan Aplikasi Program Smart PLS 3.0.Pengolahan data ini dimulai dengan melakukan uji validitas dan reliabilitas yaitu melalui evaluasi outer model. Ghozalidan Latan (2015) menyatakan bahwa evaluasi model pengukuran atau outer model dilakukan untuk menilai validitas dan reliabilitas model.Berikut Evaluasi model pengukuran (outer model ) untuk uji validitas dan reliabilitas.

\section{1) Uji validitas}

Uji validitas data dilakukan pada saat evaluasi outer model dengan indicator reflektif dievaluasi melalui validitas convergent dan discriminant validity.Uji convergent validity dilakukan untuk mengetahui validitas dari indicator yang digunakan. Indikator dinyatakan valid dengan nilai loading factor berkisar di atas 0,50 . Hasil evaluasi convergent validity dapat dilihat pada gambar 1yang menunjukkan bahwa hasil ouput analisis dapat dilihat bahwa semua konstruk dengan indicator reflektif menghasilkan nilai loading factor $>0,5$. Ghozali dan Latan (2015) Convergent validity dari measurement model dengan indicator reflektif dapat dilihat dari korelasi antara score item / indicator dengan score konstruknya. Indikator individu dianggap reliable jika memiliki nilai korelasi diatas 0,70. Namun pada riset pengembangan skala loading 0,50-0,60 masih dapat diterima. Artinya bahwa semua indicator konstruk adalah valid.

Pengaruh Pengendalian Internal, Ketaatan Aturan Akuntansi Terhadap Akuntabilitas Keuangan dengan Pencegahan Kecurangan (Fraud) sebagai Variabel Intervening pada Travel Haji dan Umrah di Kotamadya Jambi 


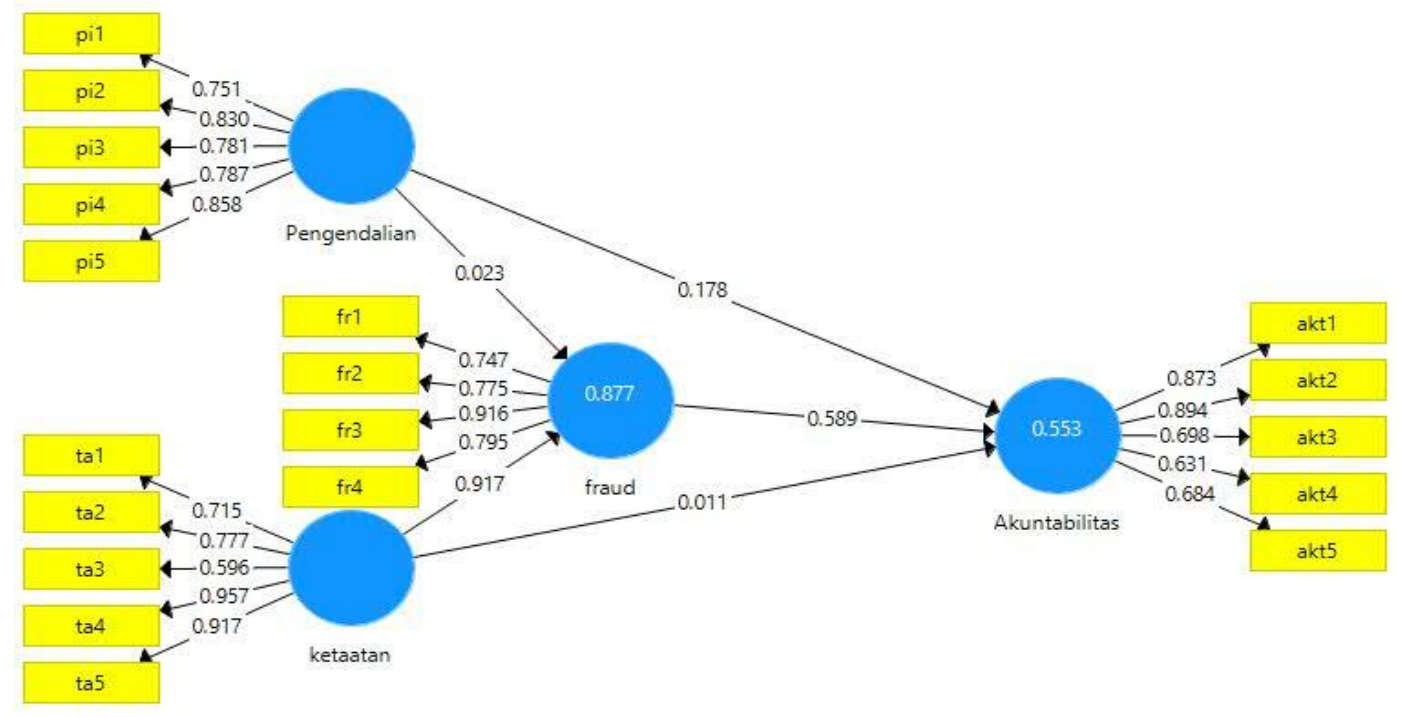

Gambar 2. Loading Factor

Tabel 7

Outer Loading

\begin{tabular}{llcc}
\hline Variabel & Indikator & Outer Loading & Keterangan \\
\hline Akuntabilitas & AKT1 & 0.873 & Valid \\
& AKT2 & 0.894 & Valid \\
& AKT3 & 0.698 & Valid \\
& AKT4 & 0.631 & Valid \\
Ketaatan Aturan & AKT5 & 0.684 & Valid \\
Akuntansi & TA1 & 0.715 & Valid \\
& TA2 & 0.777 & Valid \\
& TA3 & 0.596 & Valid \\
Pengendalian Internal & PI1 & 0.957 & Valid \\
& PI2 & 0.917 & Valid \\
& PI3 & 0.751 & Valid \\
& PI4 & 0.830 & Valid \\
& PI5 & 0.781 & Valid \\
Pencegahan Fraud & FR1 & 0.787 & Valid \\
& FR2 & 0.858 & Valid \\
& FR3 & 0.747 & Valid \\
& FR4 & 0.775 & Valid \\
\hline
\end{tabular}

Sumber : Hasil output Smart PLS 3.0 (2017)

Berdasarkan tabel 7 diatas seluruh indicator dinyatakan valid karena nilai loading faktornya berkisar diatas 0,50 .

\section{Uji Discriminant Validity}

Pengaruh Pengendalian Internal, Ketaatan Aturan Akuntansi Terhadap Akuntabilitas Keuangan dengan Pencegahan Kecurangan (Fraud) sebagai Variabel Intervening pada Travel Haji dan Umrah di Kotamadya Jambi 
Uji Discriminant validity dilakukan untuk mengetahui korelasi antara tiap indicator dengan semua variabel laten yang ada. Seluruh indicator dinyatakan valid jika nilai korelasi cross loading seluruh indicator yang digunakan dalam membentuk variabel laten, lebih besar dibandingkan dengan korelasi terhadap variabel laten yang lain (Ghozali \& latan, 2015). Nilai korelasi cross loading masing-masing variabel dijelaskan pada tabel 8 Berdasarkan tabel 8 , uji Discriminant validity menunjukkan nilai korelasi cross loading seluruh indicator dibandingkan variabel laten lainnya.

Tabel 8

Uji Discriminant Validity

\begin{tabular}{lrrrr}
\hline & Akuntabilitas & Pengendalian & \multicolumn{1}{l}{ Fraud } & \multicolumn{1}{c}{ Ketaatan } \\
\hline AKT1 & 0.873 & 0.536 & 0.689 & 0.730 \\
AKT2 & 0.894 & 0.345 & 0.528 & 0.468 \\
AKT3 & 0.698 & 0.597 & 0.710 & 0.562 \\
AKT4 & 0.631 & 0.509 & 0.353 & 0.410 \\
AKT5 & 0.684 & 0.361 & 0.320 & 0.393 \\
FR1 & 0.522 & 0.445 & 0.530 & 0.607 \\
FR2 & 0.575 & 0.899 & 0.872 & 0.822 \\
FR3 & 0.713 & 0.695 & 0.926 & 0.916 \\
FR4 & 0.548 & 0.367 & 0.494 & 0.635 \\
PI1 & 0.572 & 0.751 & 0.464 & 0.459 \\
PI2 & 0.644 & 0.830 & 0.624 & 0.611 \\
PI3 & 0.459 & 0.781 & 0.590 & 0.667 \\
PI4 & 0.466 & 0.787 & 0.746 & 0.819 \\
PI5 & 0.390 & 0.858 & 0.612 & 0.656 \\
TA1 & 0.270 & 0.719 & 0.581 & 0.715 \\
TA2 & 0.637 & 0.493 & 0.892 & 0.777 \\
TA3 & 0.625 & 0.461 & 0.460 & 0.596 \\
TA4 & 0.636 & 0.843 & 0.853 & 0.957 \\
TA5 & 0.590 & 0.741 & 0.852 & 0.917 \\
\hline
\end{tabular}

Sumber : Hasil output Smart PLS 3.0 (2018)

\section{2) Uji Reliability}

Pengujian reliabilitas untuk data semantic differensial dilaksanakan untuk mengetahui apakah kuesioner reliable atau tidak . Uji reliabilitas dilaksanakan dengan meng gunakan uji Average Variance Extranced ( $A V E)$, dan Uji Composite reliability

Tabel 9 Average Variance Extranced ( AVE)

\begin{tabular}{lrl}
\hline \multicolumn{1}{c}{ Variabel Laten } & AVE & Keterangan \\
\hline Akuntabilitas & 0.583 & Reliabel \\
Pencegahan Fraud & 0.657 & Reliabel \\
Ketaatan Aturan Akuntansi & 0.645 & Reliabel \\
Pengendalian Internal & 0.644 & Reliabel \\
\hline
\end{tabular}

Sumber : Hasil output Smart PLS 3.0 (2018)

Pengaruh Pengendalian Internal, Ketaatan Aturan Akuntansi Terhadap Akuntabilitas Keuangan dengan Pencegahan Kecurangan (Fraud) sebagai Variabel Intervening pada Travel Haji dan Umrah di Kotamadya Jambi 
Berdasarkan tabel 9 diatas dapat dijelaskan bahwa nilai AVE masing-masing variabel Pencegahan fraud, pengendalian internal, ketataan akuntansi adalah > 0,5. Nilai AVE dari masing - masing variabel penelitian diatas diartikan reliabel .

\section{Pengujian Hipotesis}

Pengujian hipotesis bertujuan untuk menguji pengaruh pengendalian internal dan ketaatan aturan akuntansi secara langsung dan dengan mengunakan variabel pencegahan kecurangan ( $f r a u d)$ terhadap akuntabilitas dengan tingkat signifikansi sebesar 5\%.Tabel result for inner weights dari hasil running bootstrapping digunakan untuk mengetahui pengaruh langsung antar variabel dari masing-masing hipotesis. Caranya melihat nilai koefesien jalur dari masingmasing hipotesis dan nilai $\mathrm{t}$-stat. Koefesien ini bersumber dari kolom original sample estimate.Seperti terlihat pada gambar 3 output bootstrapping :

pengaruh langsung signifikan dari masing-masing hipotesis. Berikut adalah diagram nilai T-statistik berdasarkan output dengan smart PLS versi 3 disajikan pada gambar 3 .

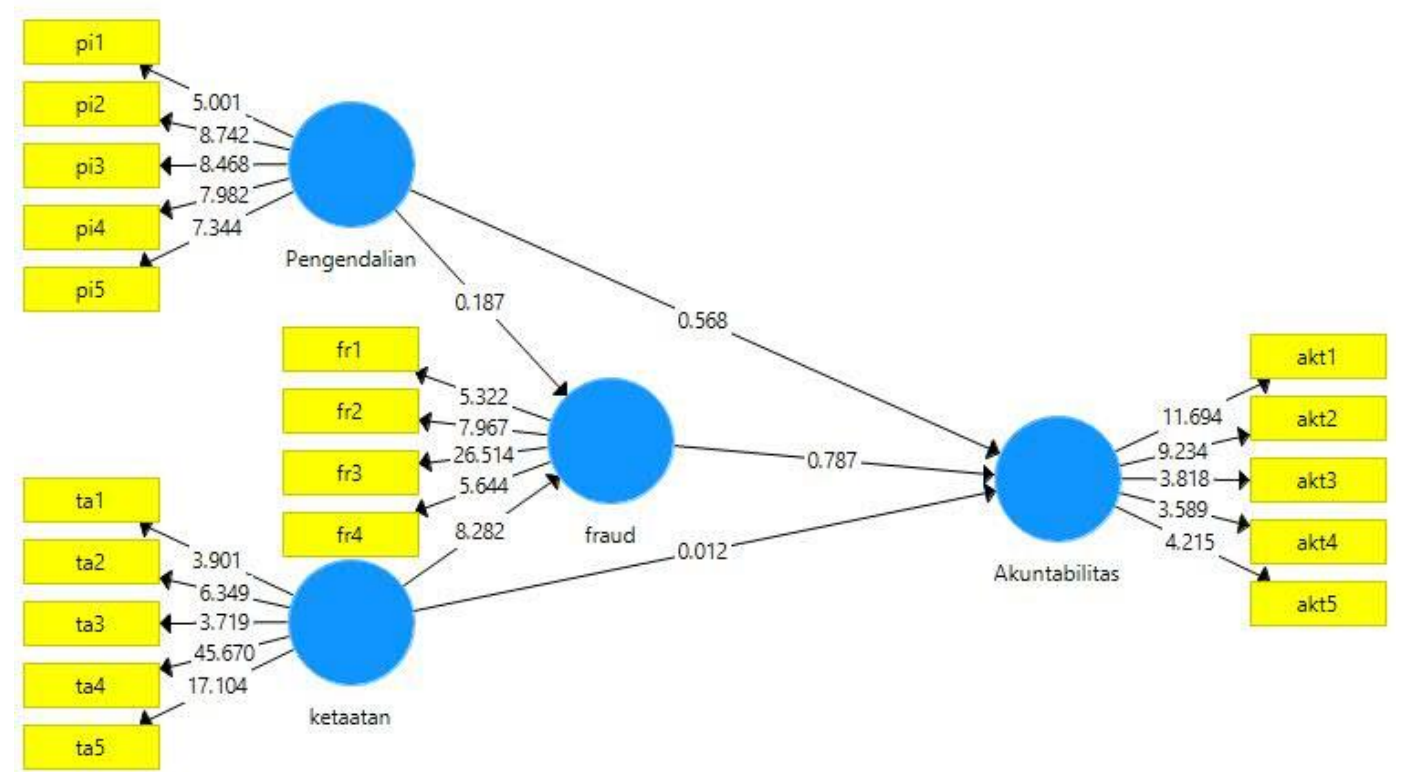

Gambar 3. Output Bootstrapping

\section{Model Struktural}

Model struktural adalah model yang menghubungkan variabel laten exogenous dengan variabel laten endogenous atau hubungan variabel endogenous dengan variabel endogenous lainnya, yang dijelaskan sebagai berikut :

Tabel 10

Rangkuman Hasil Uji Statistik

\begin{tabular}{llrrrr}
\hline Struktur & \multicolumn{1}{c}{ Jalur } & Koefesien & T hitung & P Values & R Square \\
\hline Pertama & Pengendalian --> Fraud & 0.125 & 0.187 & 0.852 & 0,877 \\
& Ketaatan --> Fraud & 0.111 & 8.282 & 0.000 &
\end{tabular}

Pengaruh Pengendalian Internal, Ketaatan Aturan Akuntansi Terhadap Akuntabilitas Keuangan dengan Pencegahan Kecurangan (Fraud) sebagai Variabel Intervening pada Travel Haji dan Umrah di Kotamadya Jambi 


\begin{tabular}{llcccc} 
Kedua & $\begin{array}{l}\text { Pengendalian --> } \\
\text { Akuntabilitas }\end{array}$ & 0.313 & 0.568 & 0.570 & 0.553 \\
& & & & \\
& Fraud $-->$ Akuntabilitas & 0,748 & 0.787 & 0.431 & \\
Ketaatan --> Akuntabilitas & 0,903 & 0,012 & 0.990 & \\
\hline
\end{tabular}

Sumber : Hasil data diolah

\section{Pembahasan}

\section{1) Pengaruh Pengendalian internal terhadap Pencegahan Kecurangan}

Berdasarkan tabel 10 dapat dilihat nilai T-hitung variabel Pengendalian-$>$ Fraud $(0.187)$ lebih kecil dibanding $t$ kritis $(1,96)$. Karena nilai t hitung lebih kecil dibanding $\mathrm{t}$ kritis di tingkat kekeliruan 5\%. Jadi Berdasarkan hasil pengujian dapat disimpulkan bahwa pengendalian internal tidakberpengaruh secara signifikan terhadap pencegahan fraud di travel umrah di Kotamadya Jambi. Hal ini tidak sejalan dengan penelitian Kadir (2015) yang menujukkan bahwa pengendalian internal berpengaruh secara signifikan terhadap efektivitas pelaksanaan prosedur audit dalam pencegahan fraud, hal ini juga menunjukkan bahwa semakin baik pengendalian internal yang diterapkan, maka akan semakin efektif pula pelaksanaan prosedur audit dalam hal ini mencegah terjadinya tindak kecurangan. Menurut Penelitian Afkar ( 2016 )pengendalian detektif dan pengendalian represif dapat mencegah terjadinya kecurangan akuntansi.

2) Pengaruh Ketaatan aturan Akuntansi terhadap Pencegahan Kecurangan Berdasarkan tabel 10 dapat dilihat nilai T-hitung variabel Ketaatan --> Fraud (8.282) lebih besar dibanding t kritis $(1,96)$. Karena nilai t hitung lebih besar dibanding $\mathrm{t}$ kritis di tingkat kekeliruan 5\%. Jadi Berdasarkan hasil pengujian dapat disimpulkan bahwa ketaatan aturan akuntansi berpengaruh secara signifikan terhadap pencegahan fraud di travel umrah di Kotamadya Jambi. Hasil penelitian ini memberikan bukti empiris bahwa semakin baik ketaatan aturan akuntansi akan meningkatkan pencegahan fraud. Hal ini sejalan dengan penelitian Wolk and Tearney (1997), yang menjelaskan bahwa kegagalan penyusunan laporan keuangan dan penyalahgunaan asset yang disebabkan karena ketidaktaatan pada aturan akuntansi, di mana hal tersebut akan menimbulkan kecurangan.

3) Pengaruh Pengendalian internal terhadap Akuntabilitas Keuangan

Berdasarkan tabel 10 dapat dilihat nilai T-hitung variabel akuntabilitas (0.568) lebih kecil dibanding t kritis $(1,96)$. Karena nilai t hitung lebih kecil dibanding t kritis di tingkat kekeliruan 5\%. Jadi Berdasarkan hasil pengujian dapat disimpulkan bahwa pengendalian internal melalui pencegahan kecurangan tidak berpengaruh secara signifikan terhadap akuntabilitas di travel umrah di Kotamadya Jambi. Hasil penelitian ini memberikan bukti empiris bahwa pengendalian internal pada travel umrah tidak dapat meningkatkan akuntabilitas.Hal ini tidak sejalan dengan penelitian Pradayani (2014) yang menunjukkan bahwa keefektifan pengendalian internal berpengaruh pada akuntabilitas organisasi melalui kecenderungan kecurangan akuntansi.

4) Pengaruh Ketaatan Aturan Akuntansi terhadap Akuntabilitas Berdasarkan tabel 10 dapat dilihat nilai T-hitung variabel akuntabilitas (0.012) lebih kecil dibanding t kritis $(1,96)$. Karena nilai t hitung lebih kecil dibanding

Pengaruh Pengendalian Internal, Ketaatan Aturan Akuntansi Terhadap Akuntabilitas Keuangan dengan Pencegahan Kecurangan (Fraud) sebagai Variabel Intervening pada Travel Haji dan Umrah di Kotamadya Jambi 
t kritis di tingkat kekeliruan 5\%. Jadi Berdasarkan hasil pengujian dapat disimpulkan bahwa ketaatan aturan akuntansi tidak berpengaruh secara signifikan terhadap akuntabilitas di travel umrah di Kotamadya Jambi. Hasil penelitian ini memberikan bukti empiris bahwa ketaatan aturan akuntansi pada travel umrah tidak dapat meningkatkan akuntabilitas keuangan.

5) Pengaruh Pengendalian keuangan dan ketaatan aturan akuntansu melalui Pencegahan Kecurangan sebagai variabel intervening terhadap Akuntabilitas

Berdasarkan tabel 10 dapat dilihat nilai T-hitung variabel Pencegahan Fraud-$>$ Akuntabilitas(0.787) lebih kecil dibanding t kritis $(1,96)$. Karena nilai t hitung lebih kecil dibanding t kritis di tingkat kekeliruan 5\%. Jadi berdasarkan hasil pengujian dapat disimpulkan bahwa pengendalian keuangan dan ketaatan aturan akuntansi melalui pencegahan kecurangan ( fraud) tidak berpengaruh secara signifikan terhadap akuntabilitas keuangan di travel haji dan umrah di Kotamadya Jambi.

\section{SIMPULAN}

Berdasarkan hipotesis, hasil penelitian dan pembahasan maka dapat ditarik kesimpulan sebagai berikut:

1) Pengendalian internal tidak berpengaruh secara signifikan terhadap pencegahan kecurangan,

2) Ketaatan aturan akuntansi berpengaruh secara signifikan terhadap pencegahan kecurangan,

3) Pengendalian internal tidak berpengaruh secara signifikan terhadap akuntabilitas keuangan

4) Ketaatan aturan akuntansi tidak berpengaruh secara signifikan terhadap akuntabilitas keuangan

5) Pengendalian internal dan ketaatan aturan akuntansi melalui pencegahan kecurangan (fraud) tidak berpengaruh secara signifikan terhadap akuntabilitas.

\section{DAFTAR PUSTAKA}

Afkar, Taudlikhul, 2016. Efektivitas Pengendalian Preventif, Pengendalian Detektif, dan Pengendalian Represif terhadap Pencegahan Kecurangan Akuntansi, Jurnal Akuntansi, Vol. 21.

Agustiawan.(2016), Dimensi-dimensi Akuntabilitas dan Kinerja Organisasi Sektor Publik, Tesis, Universitas Gajah Mada.

Amanda, Rezya Friska, (2015), Pengaruh Peran Audit Intern Dan Efektivitas Pelaksanaan Pengendalian Intern Pemerintah Terhadap Kecenderungan Kecurangan Akuntansi (Studi Empiris pada SKPD Pemerintah Kota Padang Panjang), Jurnal Akuntansi Vol. 3

Aranta, Petra Zulia, (2013), Pengaruh Moralitas Aparat Dan Asimetri Informasi Terhadap Kecenderungan Kecurangan Akuntansi (Studi Empiris Pemerintah Kota Sawahlunto), Jurnal Akuntansi, Vol. 1.

Bartenputra, Adrian, (2016), Pengaruh Kesesuaian Kompensasi, Ketaatan Akuntansi dan Asimetri Informasi terhadap Kecenderungan Kecurangan Akuntansi (Studi empiris pada SKPD Kota Bukittinggi), Jurnal Akuntansi, Vol. 4.

Pengaruh Pengendalian Internal, Ketaatan Aturan Akuntansi Terhadap Akuntabilitas Keuangan dengan Pencegahan Kecurangan (Fraud) sebagai Variabel Intervening pada Travel Haji dan Umrah di Kotamadya Jambi 
Cooper, Donald R and Schindler, Pamela S, 2017. Metode Penelitian Bisnis Edisi 12, Buku 1 : Penerbit The Mc Graw- Hill Companies, Inc

Davia, Howard R.et al 2000. Fraud 101: Techniques and Strategies for Detection. John Wiley \& Sons

Dorminey, Jack, Fleming A.Scott Jo Kranacher, Mary ,and Jr. Richard A Riley, 2012. The Evolution of Fraud Theory Issues In Accounting Education . American Accounting Association, Vol 27 , No 2 DOI : 10.2308/iace50131 pp.555-579. Melalui (www.gen.lib.rus.ec).

Dunia Ahmad, Firdaus.2013. Pengantar Akuntansi . Jakarta: Penerbit Fakultas Ekonomi Universitas Indonesia

Ghozali.2006. Structural Equation Modeling PLS, Semarang : Penerbit Universitas Diponegoro

Ghozali, Imam dan Latan , Hengky , 2015, Partial Least Square Konsep, Teknik , dan Aplikasi Menggunakan Program Smart PLS 3.0 Untuk penelitian Empiris. Semarang: Penerbit Universitas Diponegoro

Kadir, Hernawati. (2015), Pengaruh Penendalian Internal Dan Kompetensi Auditor Terhadap Efektivitas Pelaksanaan Prosedur Audit Dalam Pencegahan Fraud, Jurnal Akuntansi (JAk).

Krismiaji, 2010. Sistem Informasi Akuntansi . Yokyakarta: UPP AMP YKPN.

Mahmudi .2005 . Analisis laporan pemerintah daerah, Sekolah tinggi ilmu manajemen YKPN, Yokyakarta

Mufidah. (2015), Analisis Pengaruh Independensi, Obyektifitas, Integritas, Kompetensi, Pengalaman Kerja dan Skeptisisme Profesional Terhadap Kualitas Hasil Pemeriksaan di Lingkungan Inspektorat Provinsi Jambi, Jurnal Ilmiah Universitas Batanghari Jambi, Vol.15, No.2.

Mulyadi.2002. Sistem Informasi Akuntansi.Jakarta : Penerbit Salemba Empat

Rahmawati, Ardiana peri .2012 . Analisis Pengaruh Faktor internal dan Moralitas Manajemen Terhadap kecendrungan kecurangan Akuntansi . Tesis.Semarang . Universitas Diponegoro

Siregar, Baldric , Bambang Suripto , Dody hapsoro, Eko widodo ,dan Biyanto . 2017 . Akuntansi Manajemen. Jakarta : Penerbit Salemba Empat

Tuanakotta, Theodorus M. 2013 .Akuntansi Forensik \& Audit Investigatif.Jakarta : Penerbit Salemba Empat

Wibowo, Eka A. danHeru, Kristanto (2017), Korupsi dalam Pelayanan Gereja: Analisis Potensi Penyimpangan dan Pengendalian Internal.

Wolk, H.I. and M.G. Tearney. (1997), Accounting Theory: A Conceptual and Institutional Approach. Adisi 4.International Thomson Publishing.

Yendrawati, Reni, (2013), Pengaruh Sistem Pengendalian Intern dan Kapasitas Sumber Daya Manusia Terhadap Kualitas Informasi Laporan Keuangan dengan Faktor Eksternal sebagai Variabel Moderating, Jurnal Akuntansi \& Auditing Indonesia (JAAI), Vol. 17.

Zainal, Riski, (2013), Pengaruh Efektifitas Pengendalian Intern, Asimetri Informasi dan Kesesuaian Kompensasi terhadap Kecenderungan Kecurangan Akuntansi (Fraud)(Studi Empiris Kantor Cabang Bank Pemerintah Dan Swasta Di Kota Padang), Jurnal Akuntansi, Vol. 1.

Pengaruh Pengendalian Internal, Ketaatan Aturan Akuntansi Terhadap Akuntabilitas Keuangan dengan Pencegahan Kecurangan (Fraud) sebagai Variabel Intervening pada Travel Haji dan Umrah di Kotamadya Jambi 